\title{
A COMPARISON OF ISONIAZID WITH MODIFIED INSULIN THERAPY IN NEUROTIC STATES
}

\author{
BY
}

\author{
MAURICE SILVERMAN
}

\author{
From Claybury Hospital, Woodford Bridge, Essex
}

A method of insulin treatment directed towards increasing the patient's weight and feeling of physical well-being and reducing feelings of tension and anxiety is commonly employed in the treatment of selected neurotic conditions (Sargant and Craske, 1941 ; Tomlinson and Ozarin, 1942 ; Sargant and Slater, 1948). The dosage of insulin and the taking of food are so arranged that actual coma is never reached. This form of treatment has become known as modified insulin therapy. However, a striking increase in appetite and food consumption, with apparent restoration in energy, was also noted by Robitzek and Selikoff (1952) in their investigations on the effect of isonicotinic acid hydrazide (isoniazid) in tuberculous patients, and the possibility therefore arose of being able to employ isoniazid in the physical therapy of neurotic breakdowns. It was considered that, if isoniazid was found to be effective as an alternative to modified insulin therapy, the ease of administration and simple supervision involved in its use might confer upon it practical advantages over insulin. With the latter possibility in mind, an investigation was planned to test the relative merits of isoniazid and insulin in the treatment of neurotic disorders.

\section{Materials and Methods}

“Modified Insulin Group".--The patients, who were all males, fasted from $8 \mathrm{p} . \mathrm{m}$. the previous evening. At 7 a.m. the following day they were given an intramuscular injection of 20 units soluble insulin and this was immediately followed by the oral administration of two inert tablets (specially prepared by Messrs. Savory and Moore). These tablets were employed to control the effect of giving isoniazid tablets in the other group of subjects under investigation. At 10 a.m. the patients received a standard breakfast consisting of the following :

$20 \mathrm{oz}$. (weighed out) boiled potatoes.

4 slices bread and margarine.

1 cup of coffee.

Jam (or marmalade) as required.
At 7 p.m. the patients were given two further inert tablets for control purposes. The dose of insulin was increased by 10 units each day until a maximum of 40 units was reached. All the patients remained on the standard hospital diet and they were not allowed to obtain eatables from outside the hospital. In connexion with the latter, it should be stated that, for the patients involved, all parole was cancelled during the investigation and the relatives were not allowed to bring any foodstuffs into the hospital. Each patient underwent treatment daily (with the exception of Sundays) for a period of four weeks.

The investigation was carried out in a special room which was normally utilized for modified insulin therapy and the nurses in charge were experienced in this form of treatment.

"Isoniazid Group".-Two tablets of isoniazid (100 mg. each) were given at 7 a.m. and 7 p.m. respectively in place of the inert tablets included in the " modified insulin group" and, in addition, sterile water was substituted for the soluble insulin administered to the other group of subjects. Apart from these differences, the remaining procedures were identical in each of the two groups.

None of the patients included was informed about the two separate types of treatment employed. Strict secrecy was maintained on this point so that the subjects were quite unaware of the different drugs involved. The absence of any apparent distinction between the two groups was further emphasized by the fact that the words "Insulin Treatment" were printed on the door leading into the room utilized for this study.

The ages of the patients, and the conditions from which they were suffering, are shown in Tables I and II.

It will:.be seen that only eight patients were included in each of the two groups. The original intention, however, was to study a larger series of subjects, but due to the recorded results and subsequent clinical impressions of how the patients 
TABLE I

CASES ON MODIFIED INSULIN THERAPY

\begin{tabular}{c|r|l|r|r|r}
\hline $\begin{array}{c}\text { Case } \\
\text { No. Admitted }\end{array}$ & \multicolumn{1}{|c|}{ Diagnosis } & Age & $\begin{array}{l}\text { Therapy } \\
\text { Begun }\end{array}$ & \multicolumn{1}{|c|}{$\begin{array}{c}\text { Therapy } \\
\text { Ended }\end{array}$} \\
\hline 1 & 19.6 .52 & Anxiety state & 37 & 10.7 .52 & 6.8 .52 \\
2 & 15.7 .52 & Hysteria & 28 & 25.7 .52 & 21.8 .52 \\
3 & 30.7 .52 & Anxiety state & 27 & 13.8 .52 & 9.9 .52 \\
4 & 23.8 .52 & Anxiety state & 35 & 27.8 .52 & 23.9 .52 \\
5 & 2.9 .52 & Anxiety state & 24 & 8.9 .52 & 5.10 .52 \\
6 & 4.11 .52 & Neurotic depressive reaction & 29 & 11.11 .52 & 8.12 .52 \\
7 & 6.12 .52 & Neurotic depressive reaction & 31 & 10.12 .52 & 6.1 .53 \\
8 & 9.12 .52 & Anxiety state & 26 & 12.12 .52 & 8.1 .53 \\
\hline
\end{tabular}

TABLE II

CASES ON ISONIAZID

\begin{tabular}{c|r|l|r|r|r}
\hline $\begin{array}{c}\text { Case } \\
\text { No. }\end{array}$ & Admitted & \multicolumn{1}{|c|}{ Diagnosis } & Age & $\begin{array}{l}\text { Therapy } \\
\text { Begun }\end{array}$ & $\begin{array}{l}\text { Therapy } \\
\text { Ended }\end{array}$ \\
\hline 1 & 7.7 .52 & Anxiety state & 19 & 11.7 .52 & 7.8 .52 \\
2 & 11.7 .52 & Neurotic depressive reaction & 32 & 16.7 .52 & 12.8 .52 \\
3 & 11.7 .52 & Neurotic depressive reaction & 32 & 16.7 .52 & 12.8 .52 \\
4 & 13.8 .52 & Neurotic depressive reaction & 38 & 14.8 .52 & 10.9 .52 \\
5 & 29.8 .52 & Neurotic depressive reaction & 21 & 3.9 .52 & 30.9 .52 \\
6 & 6.10 .52 & Anxiety state & 34 & 8.10 .52 & 4.11 .52 \\
7 & 7.10 .52 & Anxiety state & 38 & 12.10 .52 & 8.11 .52 \\
8 & 30.12 .52 & Anxiety state & 35 & 12.1 .53 & 8.2 .53 \\
\hline
\end{tabular}

responded, it was considered unfair to extend the investigation to other subjects.

The changes in body weight and the subjective response to treatment were investigated in each group of patients.

\section{Results}

Changes in Body Weight.-Each subject was weighed immediately before beginning treatment (in the early morning) and on the morning following the last day of treatment. The same scales were utilized throughout and the same male nurse weighed each patient. The findings are shown in Tables III and IV.

It will be seen that in the group undergoing modified insulin therapy there was a consistently greater increase in weight than was to be found in the " isoniazid group". Though the total number of subjects investigated was small, it was considered of interest to apply a statistical test to determine whether or not these increased weight gains were

TABLE III

CHANGES IN BODY WEIGHT BEFORE AND AFTER MODIFIED INSULIN THERAPY

\begin{tabular}{c|cc|cc|c}
\hline $\begin{array}{c}\text { Case } \\
\text { No. }\end{array}$ & $\begin{array}{c}\text { Weight before } \\
\text { Treatment } \\
\text { (st. lb.) }\end{array}$ & $\begin{array}{c}\text { Weight after } \\
\text { Treatment } \\
\text { (st. lb.) }\end{array}$ & $\begin{array}{c}\text { Weight Gain } \\
\text { (lb.) }\end{array}$ \\
\hline 1 & 8 & 10 & 9 & 4 & 8 \\
2 & 9 & 9 & 10 & 1 & 6 \\
3 & 8 & 12 & 9 & 7 & 9 \\
4 & 8 & 1 & 8 & 7 & 6 \\
5 & 6 & 6 & 7 & 1 & 9 \\
6 & 10 & 10 & 11 & 7 & 11 \\
7 & 8 & 3 & 9 & 4 & 15 \\
8 & 8 & 7 & 9 & 3 & 10 \\
\hline
\end{tabular}

TABLE IV

CHANGES IN BODY WEIGHT BEFORE AND AFTER ISONIAZID TREATMENT

\begin{tabular}{|c|c|c|c|}
\hline $\begin{array}{l}\text { Case } \\
\text { No. }\end{array}$ & $\begin{array}{l}\text { Weight before } \\
\text { Treatment } \\
\text { (st. lb.) }\end{array}$ & $\begin{array}{l}\text { Weight after } \\
\text { Treatment } \\
\text { (st. lb.) }\end{array}$ & $\begin{array}{c}\text { Weight Gain } \\
\text { (lb.) }\end{array}$ \\
\hline $\begin{array}{l}1 \\
2 \\
3 \\
4 \\
5 \\
6 \\
7\end{array}$ & $\begin{array}{rr}9 & 9 \\
8 & 7 \\
8 & 2 \\
9 & 2 \\
10 & 7 \\
7 & 12 \\
8 & 7\end{array}$ & $\begin{array}{rr}9 & 12 \\
8 & 11 \\
8 & 4 \\
9 & 6 \\
10 & 7 \\
8 & 2 \\
8 & 6\end{array}$ & $\begin{array}{c}3 \\
4 \\
2 \\
4 \\
0 \\
4 \\
\text { No gain }\end{array}$ \\
\hline 8 & $\begin{array}{ll}8 & 12\end{array}$ & 90 & 2 \\
\hline
\end{tabular}

likely to have been due to chance. Since the average initial weights did not differ significantly $(P>0.7)$, the difference between the weight gains in the two groups was probably real $(\mathrm{P}<0.001)$.

Subjective Response to Treatment.-On the day following the completion of the course of treatment, each patient was asked, " Do you think the treatment has had any effect on you?" If the reply to the latter was in the affirmative, the subject was further asked, "What effect has it had ?" The findings are shown in Tables V and VI.

TABLE V

SUBJECTIVE RESPONSE TO TREATMENT (MODIFIED INSULIN)

\begin{tabular}{|c|c|c|}
\hline $\begin{array}{l}\text { Case } \\
\text { No. }\end{array}$ & $\begin{array}{c}\text { Positive } \\
\text { Effect }\end{array}$ & Nature of Effect \\
\hline 1 & Yes & "Sort of built me up. Made me physically fit \\
\hline 2 & Yes & "I can eat breakfast now.; I couldn't before. \\
\hline 3 & Yes & $\begin{array}{l}\text { "I feel a lot stronger and I'm eating more. I've } \\
\text { got an appetite for my breakfast now. I feel a } \\
\text { lot better in myself. More jovial, like." }\end{array}$ \\
\hline 4 & Yes & $\begin{array}{l}\text { "It's made me feel stronger. I can work and } \\
\text { I've got more confidence in myself." }\end{array}$ \\
\hline 5 & Yes & $\begin{array}{l}\text { "I've got more confidence, in myself now. I } \\
\text { feel much stronger as well." }\end{array}$ \\
\hline 6 & Yes & "I feel much better. I don't feel so nervous. \\
\hline 7 & Yes & $\begin{array}{l}\text { "It's certainly made me put on weight and I feel } \\
\text { more lively. I certainly don't get so depressed } \\
\text { as I did," }\end{array}$ \\
\hline 8 & Yes & "It's certainly made me more vigorous." \\
\hline
\end{tabular}

TABLE VI

SUBJECTIVE RESPONSE TO TREATMENT (ISONIAZID)

\begin{tabular}{|c|c|c|}
\hline $\begin{array}{l}\text { Case } \\
\text { No. }\end{array}$ & $\begin{array}{l}\text { Positive } \\
\text { Effect }\end{array}$ & Nature of Effect \\
\hline $\begin{array}{l}1 \\
2 \\
3\end{array}$ & $\begin{array}{l}\text { No } \\
\text { Yes } \\
\text { Yes }\end{array}$ & $\begin{array}{l}\text { Nil applies. } \\
\text { "More invigorated." } \\
\text { "I've never felt so well in my life and I've never }\end{array}$ \\
\hline $\begin{array}{l}4 \\
5\end{array}$ & $\begin{array}{c}\text { Yes } \\
\text { “It's hard }\end{array}$ & $\begin{array}{l}\text { "It's given me a rest." } \\
\text { " My legs ache when I lie in bed and I can't sleep." }\end{array}$ \\
\hline 6 & $\begin{array}{l}\text { to say. } \\
\text { Yes }\end{array}$ & $\begin{array}{l}\text { "Done me the world of good, without telling } \\
\text { lies." }\end{array}$ \\
\hline 7 & Yes & $\begin{array}{l}\text { " Honestly speaking, it made a big change inside } \\
\text { me. It stopped the panics I had." }\end{array}$ \\
\hline 8 & Yes & $\begin{array}{l}\text { "I feel a different man altogether. I've regained } \\
\text { my confidence and I feel my normal self." }\end{array}$ \\
\hline
\end{tabular}


Table $\mathrm{V}$ shows that almost all the patients on modified insulin therapy considered that the treatment had increased their appetite and enabled them to put on weight. In fact, patient No. 6 was the only subject in this group who did not explicitly state that the treatment had had a beneficial effect on his physical condition. In the group treated with isoniazid, however, the replies to questioning were of a much more nebulous character. In this latter group, no subject, apart, perhaps, from patient No. 2, made any obvious reference to the effect of the treatment on his physical well-being, and two of the subjects (Nos. 1 and 5) did not consider that the treatment was of any positive value whatsoever.

It should be stated that, in addition to the recorded observations on body weight and the subjects' own impressions of the effect of treatment, there was general agreement between the nurses in charge of the patients and myself on the fact that the clinical progress-both physical and psychological-of the patients treated by modified insulin therapy appeared to be consistently superior to that of the patients treated with isoniazid. It was for this reason that the investigation was not extended to a larger series of subjects.

\section{Discussion}

Robitzek and Selikoff (1952), in their investigations of the effect of isonicotinic acid hydrazide on patients suffering from "hopeless" pulmonary tuberculosis, noticed "a sharp return in sense of well-being", markedly increased appetite, rapid weight gain, and restoration of energy. These beneficial effects have not been reproduced in the present study of neurotic patients in whom overt evidence of tuberculosis was not present. It is true that most of the subjects in the "isoniazid group" stated that they felt greatly improved following treatment but it seems probable that this was largely due to the suggestive effect of the régime. In the words of Robitzek and Selikoff (1952), " . . . it is a matter of major perception to eliminate the psychologic aspects inherent in a group entirely aware that it is receiving special attention." The fact remains that, though both groups of subjects were taking part in a superficially similar programme of treatment, the increase in weight of the patients undergoing modified insulin therapy was significantly greater than that of the " isoniazid group" and this observation was supported by the subjective response of the patients to treatment.

It would seem that the increase in weight and general physical well-being consequent upon the use of isoniazid in pulmonary tuberculosis is directly due to the effect of therapy on the actual tuberculous process. Alternatively, work on the "animal protein factor" (e.g., Cunha, Burnside, Buschman, Glasscock, Pearson, and Shealy, 1949 ; Biely and March, 1951) suggests the possibility that isoniazid may produce some of its effects by virtue of being an animal protein factor. This mode of action receives support from Barnard, Orens, and Schwartz (1952), who state that isoniazid may induce a rapid gain in flesh in many non-tuberculous conditions. (They suggest, on the basis of their views on the mechanisms involved, that the designation "A.P.F." should be used to denote " anabolism-promoting factor".)

\section{Summary and Conclusions}

An investigation was carried out in two groups of male subjects to test the relative merits of isoniazid and modified insulin therapy in the physical treatment of neurotic disorders.

In the group of subjects undergoing modified insulin therapy there was a significantly greater increase in weight than was to be found in the group treated with isoniazid. This observation was supported by the subjective response of the patients to treatment and was in agreement with the clinical impressions of those in charge of the investigation.

Reference is made to the possible mode of action of isoniazid in inducing a rapid gain in flesh in tuberculous and non-tuberculous conditions.

It is concluded that isoniazid is unsuitable as a substitute for modified insulin therapy in the treatment of neurotic states.

It is a pleasure to thank Dr. J. S. Harris, PhysicianSuperintendent, Claybury Hospital, for encouraging me to carry out this investigation on suitable patients in the hospital. My thanks are also due to Dr. Z. A. Leitner, clinical assistant, St. Mary's Hospital, London, for helpful suggestions and advice, and to Dr. W. J. Martin, Statistical Research Unit (Medical Research Council), London School of Hygiene and Tropical Medicine, for advising me on the statistical treatment of the findings.

\section{REFERENCES}

Barnard, R. D., Orens, R. L., and Schwartz, M. (1952). Brit. med. J., 2, 612 .

Biely, J., and March, B. (1951). Science, 114, 330.

Cunha, T. J., Burnside, J. E., Buschman, D. M., Glasscock, R. S., Pearson, A. M., and Shealy, A. L. (1949). Arch Biochem., 23, 324 .

Robitzek, E. H., and Selikoff, I. J. (1952). Amer. Rev. Tuberc., $65,402$.

Sargant, W., and Craske, N. (1941). Lancet, 2, 212.

and Slater, E. (1948). An Introduction to Physical Methods of Treatment in Psychiatry, 2nd ed. Livingstone, Edinburgh.

Tomlinson, P. J., and Ozarin, L. D. (1942). Psychiat. Quart., 16, 167. 